\title{
Preliminary study of coconut water for graft tissues preservation in transplantation
}

\section{Estudo preliminar da água de coco para preservação de enxertos teciduais em transplante}

Jorge Miguel Schettino César ${ }^{1}$; Andy Petrolanu, TCBC-MG²; Leonardo de Souza Vasconcelos ${ }^{3}$; Valbert Nascimento Cardoso ${ }^{4}$; luciene das Graças Mota ${ }^{3}$; Alfredo José Afonso Barbosa ${ }^{5}$; Cristina Duarte Vianna Soares4; Amanda lima de Oliveira ${ }^{6}$

\author{
A
}

\begin{abstract}
Objective: to verify the effectiveness of coconut water in preserving tissues for transplant. Methods: Fifty male Wistar rats were randomly distributed in five groups, according to the following preservation solutions for tissue grafts: Group 1: Lactated Ringer; Group 2: Belzer solution; Group 3: mature coconut water; Group 4: green coconut water; Group 5: modified coconut water. In Group 5, the green coconut water has been modified like the Belzer solution. From each animal we harvasted the spleen, ovaries and skin of the back segment. These tissues were preserved for six hours in one of the solutions. Then, the grafts were reimplanted. The recovery of the function of the implanted tissues was assessed 90 days after surgery, by splenic scintigraphy and blood exame. The implanted tissues were collected for histopathological examination. Results: The serum levels did not differ among groups, except for the animals in Group 5, which showed higher levels of IgG than Group 1, and differences in relation to FSH between groups 1 and $2(p<0.001), 4$ and $2(p=0.03)$ and 5 and $2(p=0.01)$. The splenic scintigraphy was not different between groups. The ovarian tissue was better preserved in mature coconut water $(p<0.007)$. Conclusion:the coconut water-based solutions preserves spleen, ovary, and rat skin for six hours, maintaining their normal function.
\end{abstract}

Key words: Coconut, Organ preservation solutions, Autogenous transplantation, Ovary, Spleen, Skin.

\section{INTRODUCTION}

$M$ ethods to preserve organs and tissues for transplantation are associated with the suppression of metabolism by hypothermia. The blood is replaced by a preservation solution to become tolerant to the organ hypothermia. The composition of preservation solutions is critical to organ tolerance stored in hipotermia ${ }^{1-4}$. The introduction of the solution of the University of Wisconsin, or Belzer solution, at the end of the 1980s, was a major breakthrough in organ preservation ${ }^{2}$.

Studies with gametes of various animal species have shown that coconut water (endosperm of Cocosnucifera L.) can be successfully used in the preservation of pre-antral follicles of sheep and goats, and semen of sheep, pigs and humans. This solution was also tested as a means for storage and maturation of immature oocytes from bovine ovaries and as culture medium for mouse and bovine embryos ${ }^{3}$.

The objective of this study was to verify the effectiveness of coconut water in the preservation of tissue grafts, aiming atautografting, considering the high cost of the preservation solutions in use.

\section{METHODS}

This study was conducted in accordance with the recommendations of the International Standards for Animal Protection and the Brazilian Code of Animal Experimentation (1988), "Ethical Principles in Animal Experimentation", according to the Federal Law 11.794, of October 8th, 2008 and was aproved by the Ethics Committee on Animal Experimentation at UFMG under No 220/2009 and the Department of Education, Research and Extension of the Clinics Hospitalof the Faculty of Medicine, UFMG, memorandum 054/11.

Fifty three-month-old Wistar rats weighing between $200 \mathrm{~g}$ and $250 \mathrm{~g}$ were placed in appropriate cages, five animals per cage, at room temperature between $20^{\circ} \mathrm{C}$ and $28^{\circ} \mathrm{C}$ (mean $25^{\circ} \mathrm{C}$ ), natural humidity and lightdarknesscycles of $12 \mathrm{~h}$, with natural ventilation by

1. Post-Graduation Program in Surgery-Applied Sciences and Ophthalmology, Faculty of Medicine, Universidade Federal de Minas Gerais UFMG, Belo Horizonte, Minas Gerais State, Brazil; 2. Department Surgery, Faculty of Medicine, UFMG, Minas Gerais State, Brazil; 3. Department of Complementary Assessment, Faculty of Medicine, UFMG, Minas Gerais State, Brazil; 4. Faculty of Pharmacy, UFMG, Minas Gerais State, Brazil; 5. Department of Pathology, Faculty of Medicine, UFMG, Minas Gerais State, Brazil; 6. Faculty of Medicine, UFMG, Minas Gerais State, Brazil. 
mechanical exhaustion. The animals had free access to water and standard laboratory rodent chow (Labina $\AA_{\text {, }}$ Purina, Brazil) during the pre- and postoperative.

After 15 days of adaptation, the rats were randomized into five groups of ten animals each, following the guidance of statistical significance. The randomization was done by the distribution of animals in separate cages, without regard to any characteristic. All animals were from litters of the same race and origin, gathered in one group with similar ages and weights. The groups were determined by the preservation solution used: Group 1- Ringer lactate; Group 2- Belzer solution (ViaSpan, Bristol-Myers Squibb Pharmaceutical, Dublin.); Group 3- Mature coconut water; Group 4- green coconut water; and Group 5- modified coconut water.

Coconuts were obtained in the local market on the day of use; they were whole, with eight to 12 months of age. Parts of the mesocarp and endocarp were removed to expose the endosperm without injure it. After antisepsis of its surface with povidone-iodine containing $1 \%$ active iodine, (polvidona 10\%, Rioquímica, Sao Josédo Rio Preto, Sao Paulo), the endosperm was cut with sterile scalpel blade and the coconut water was aspirated with a 14G $\times 22$ peripheral catheter" (BB Braun $®$, Melsungten, Germany) and a $20 \mathrm{ml}$ plastic hypodermic syringe (BD Plastipak ${ }^{\circ}$, Curitiba, PR, Brazil) and transferred to a metal tank. The sterility of the coconut water extracted was confirmed by sampling with inoculation into Petri dishes with bacterial culture medium.

The modified coconut water solution was prepared in the Analytical Pharmaceutical Development Center at UFMG, based on the electrolyte composition of the green coconut water. Changes were made in its electrolyte composition to make it similar to the Belzer solution'. During the procedure, due to the precipitation of magnesium phosphate salt, it was necessary to reduce the solution $\mathrm{pH}$ to 7 by addition of hydrochloric acid. The final concentration of the modified solution is shown in relation to other preservation solutions and to mature and green coconut water, whose electrolyte compositions were measured by sampling and used in this study (Table 1).

The weight of the animals was checked immediately before surgery. The day of the operation was considered the first day of the experiment. Under general

Table 1 - Electrolyte composition and other components of tissue preservation solutions and green, mature and modified coconut waters $(\mathrm{mg} / \mathrm{L})^{4}$.

\begin{tabular}{|c|c|c|c|c|c|c|c|c|c|c|}
\hline & $R L$ & $E R$ & rER & UW & Celsior & LPD & HTK & $\mathrm{CV}$ & CM & $M$ \\
\hline pH & 7,4 & 7,2 & - & 7,4 & 7,3 & 7,4 & 7,1 & 6, & 6,9 & 7,0 \\
\hline $\mathrm{pH}$ & 7.4 & 7.2 & - & 7.4 & 7.3 & 7.4 & 7.1 & 6.9 & 6.9 & 7.0 \\
\hline $\mathrm{Na}^{*}$ & 234 & 180 & 2070 & 540 & 180 & 3024 & 27 & 252.08 & 466.67 & 540 \\
\hline $\mathrm{K}^{*}$ & 7.2 & 2070 & 180 & 2250 & 27 & 72 & 16.2 & 933.33 & 3000 & 2250 \\
\hline $\mathrm{Mg}^{2+}$ & - & - & - & 90 & 23.4 & - & - & 66.26 & 237.2 & 90 \\
\hline $\mathrm{Cl}^{-}$ & 196.2 & 270 & 270 & - & 74.7 & 1854 & - & - & - & 2569 \\
\hline Cálcio & 5.4 & - & - & - & 0.26 & - & - & - & - & - \\
\hline $\mathrm{SO}_{4}^{2-}$ & - & - & 90 & - & - & - & - & $<1$ & $<1$ & 90 \\
\hline $\mathrm{PO}_{4}^{3-}$ & - & 1035 & 1035 & 450 & - & 660.6 & 0 & 238.7 & 1324.58 & 450 \\
\hline $\mathrm{HCO}_{3}^{-}$ & - & 180 & 180 & - & - & - & - & - & - & - \\
\hline Glucose & - & 0.35 & .35 & - & - & - & - & NM & 583.33 & NM \\
\hline Lactobionate & - & - & - & 180 & 80 & - & - & - & - & - \\
\hline Glutathione & - & - & - & 5.4 & 3 & - & - & - & - & - \\
\hline Raffinose & - & - & - & 54 & - & - & - & - & - & - \\
\hline $\begin{array}{l}\text { Carbohydrate } \\
\text { hydroxyethyl }\end{array}$ & - & - & 0.5 & - & - & - & - & - & - & - \\
\hline Adenosine & - & - & - & 9 & - & - & - & - & - & - \\
\hline Histidine & - & - & - & - & 30 & - & 324 & - & - & - \\
\hline Tryptophan & - & - & - & - & - & - & 3.6 & - & - & - \\
\hline ketoglutarate & - & - & - & - & - & - & 1.8 & - & - & - \\
\hline Mannitol & - & - & - & - & 60 & - & 54 & - & - & - \\
\hline Glutamate & - & - & - & - & 2 & - & - & - & - & - \\
\hline Lactate & 50.4 & - & - & - & - & - & - & - & - & - \\
\hline Osmolality (mOsm/L) & L) 272 & 400 & 380 & 320 & 360 & 285 & 310 & $>300$ & $>300$ & NM \\
\hline
\end{tabular}

ER-Euro Solution-Collins, rER-Euro-Collins Solution with little potassium, UW-Wisconsin/Belzersolution, LPD - low potassium dextran Solution/ Toronto, RL-Ringer lactate, HTK-Histidine-tryptophan solution-ketoglutarate, CV-green coconut water, CM-mature coconut water, M modified coconut water, $\mathrm{In}^{+}-\mathrm{K}^{+}$sodium - potassium, $\mathrm{Mg}^{2+}$-magnesium, $\mathrm{Cl}$ Chlorine-, $\mathrm{SO}_{4}^{-2}$-sulfate, $\mathrm{PO}_{4}^{-3}$-Phosphate, $\mathrm{HCO}_{3}-$ bicarbonate, $\mathrm{NM}_{-}$ not measurable by Hidrocepe lab kit, mOsmol/L - miliosmoles per litre. 
anesthesia with intramuscular infusion of $10 \%$ ketamine hydrochloride (Agener Union, Embu, São Paulo a 60mg/ $\mathrm{kg}$ ) associated with2\% xylazine(Agener Union, Embu, São Paulo - $8 \mathrm{mg} / \mathrm{kg}$ ). We performed trichotomy of the abdominal wall and dorsal interscapular region, followed by antisepsis of the abdominal wall and back, with polyvinylpyrrolidone solution containing $1 \%$ active iodine, (polvidona 10\%, Rioquímica, São José do Rio Preto, São Paulo).

Through a laparotomy from the xiphoid process to the pelvic region, the spleen and both ovaries were removed after ligation and section of their vasculars pedicles. The spleen was cut into four segments, with a scalpel blade. These organs and tissues were immediately immersed in the preservation solution corresponding to each group and kept at $4^{\circ} \mathrm{C}$ for six hours. After closing the abdomen, a total skin segment of the animal's back was removed and immersed in the same preservation solution that already contained the spleen and ovaries. The donor site wound edges were approximated with 4-0 nylon sutures.

During six hours, with the organs kept in the preservation solution, the rats were kept in separate cages without food or water, but with free movement. After this period, the rats were anesthetized again, according to the technique described. We then withdrew the abdominal suture, opening the cavity. The four splenic fragments were sutured side by side on the greater omentum, with 4-0 nylon ${ }^{5}$. All procedures were performed under sterile conditions ${ }^{6}$. Both ovaries were fixed with 4-0 nylon stitches in the right pelvic fat ${ }^{7}$. The abdominal cavity was closed in two layers with continuous suture using 3-0 silk suture. After the abdominal operation, the cutaneous wound of the back was opened and the skin flap taken from the preservation solution was fixed on the superficial fascia of the wound bed using 4-0 nylon ${ }^{8}$.

Within three months of follow-up, five animals were evaluated daily. At the end of each follow-up period, all rats were weighed and prepared for the study of grafts functionality. The animals were anesthetized again according to the aforementioned technique.

The phagocytic activity of autogenous splenic grafts was qualitatively and quantitatively assessed by scintigraphy, using as contrast the radiopharmaceutical phytate sodium labeled with technetium-99m (99Tcmsodium phytate) 90 days after the operation. Then, after the collection of blood and death of animals, we removed three fragments of the liver left lobe and the splenic grafts to measure their radiation in a gamma counter. We calculated the radiation emitted by the splenic implants from the average measurements of the three tissue specimens. This abstraction represents the amount of colloid phagocytosed by the phagocytic mononuclear tissues of liver and spleen.

We collected Blood samples from the abdominal vena cava for measurement of red blood cells, hemoglobin, hematocrit, white blood cells, IgM, IgG, FSH and estradiol. The removal of blood caused the rat to died of hypovolemia.

After blood collection, we harvested the splenic fragments of the omentum, ovaries implanted in the pelvis and skin graft. The macroscopic appearance of the tissues was assessed and they were then immersed in a 4\% formaldehyde solution. Samples were collected for histological processing and stained with hematoxylin and eosin for examination by optical microscopy, by a single pathologist, who was unaware of the group to which the tissue belonged. The analysis was qualitative for the splenic tissue, ovarian one and skin, the values varying from one to 5 , according to the presentation of the tissue structures of these organs in comparison with the morphological structures of histologically normal skin, spleen and ovaries.

Tests used were: parametric ANOVA, nonparametric Kruskal-Wallis, the multiple comparison Tukey test, the non-parametric test for multiple comparisons, the Levene variance homogeneity test. The samples and the power of the test were obtained through the PASS software version 11. Differences were considered significant when corresponding to $p<0.05$.

\section{RESULTS}

The animals remained healthy, gaining weight during the postoperative period until their death on the 90 th day of autogenous implants. Behavioral changes were not noticed.

There was no difference in the radiotracer uptake by splenic grafts of the five groups. Serum dosages of leukocytes, erythrocytes, hemoglobin, hematocrit, IgM and estradiol showed no difference among groups regarding the tested parameters.

The group whose tissues were preserved in modified coconut solution displayed higher levels of IgG compared with the group whose preservation was in Ringer lactate $(p=0.03)$.

The animals whose tissues were preserved in Ringer's lactate showed lower values of FSH that the group with conservation in Belzer, $p<0.001$. The group whose conservation occurred in coconut solution showed lower FSH levels than the group with conservation in Belzer solution, $p$-value $=0.03$. In the group whose tissues were stored in modified coconut solution FSH levels were lower than the group with conservation in Belzer solution, $p$-value $=0.01$.

The splenic fragments reduced their size and were attached to the liver edge. Ovarian fragments were located in the pelvic fat, also reduced in size.

Skin implants evolved with areas of necrosis during the first seven days. Then granulated wound areas formed and subsequently, hardly visible scars. The microscopic study of cutaneous implants found no difference between the preservation solutions studied. Microscopic 
evaluation of the splenic implants also found no difference between the preservation solutions studied.

At microscopic analysis of the ovarian tissue, we found the preservation in mature coconut water to be more effective than the modified coconut water $(p=0.01)$ and Belzer $(p=0.007)$ (Figure 1).

\section{DISCUSSION}

The choice of tissues included in this study was due to their ease of mobilization and for being part of lines of research initiated in 19839-12.

The scintigraphic images recorded the radiotracer uptake by splenic implants with difficulty due to the overlapping of liver image ${ }^{13}$. However, the emission of radiation dosages by implanted spleen fragments left no doubt that 12 weeks were sufficient for their phagocytic functional recovery ${ }^{13,14}$. There was no difference between the conservation of liquids studied in relation to the evaluation of the function of the splenic implants by scintigraphy, which is a more sensitive method to indicate uptake by spleen cells than the blood tests ${ }^{14}$.

The higher IgG levels observed in conservation with modifiedcoconut solution than the conservation with Ringer solution can mean a better splenic preservation with that solution, perhaps because of its chemical composition. In other studies, the coconut water solution was as effective as the Braun-Collins solution in the preservation of preantral follicles in goats at $4^{\circ} \mathrm{C}$ and higher temperatures. In addition, it proved to be effective in the preservation of sperm, oocyte maturation and embryo
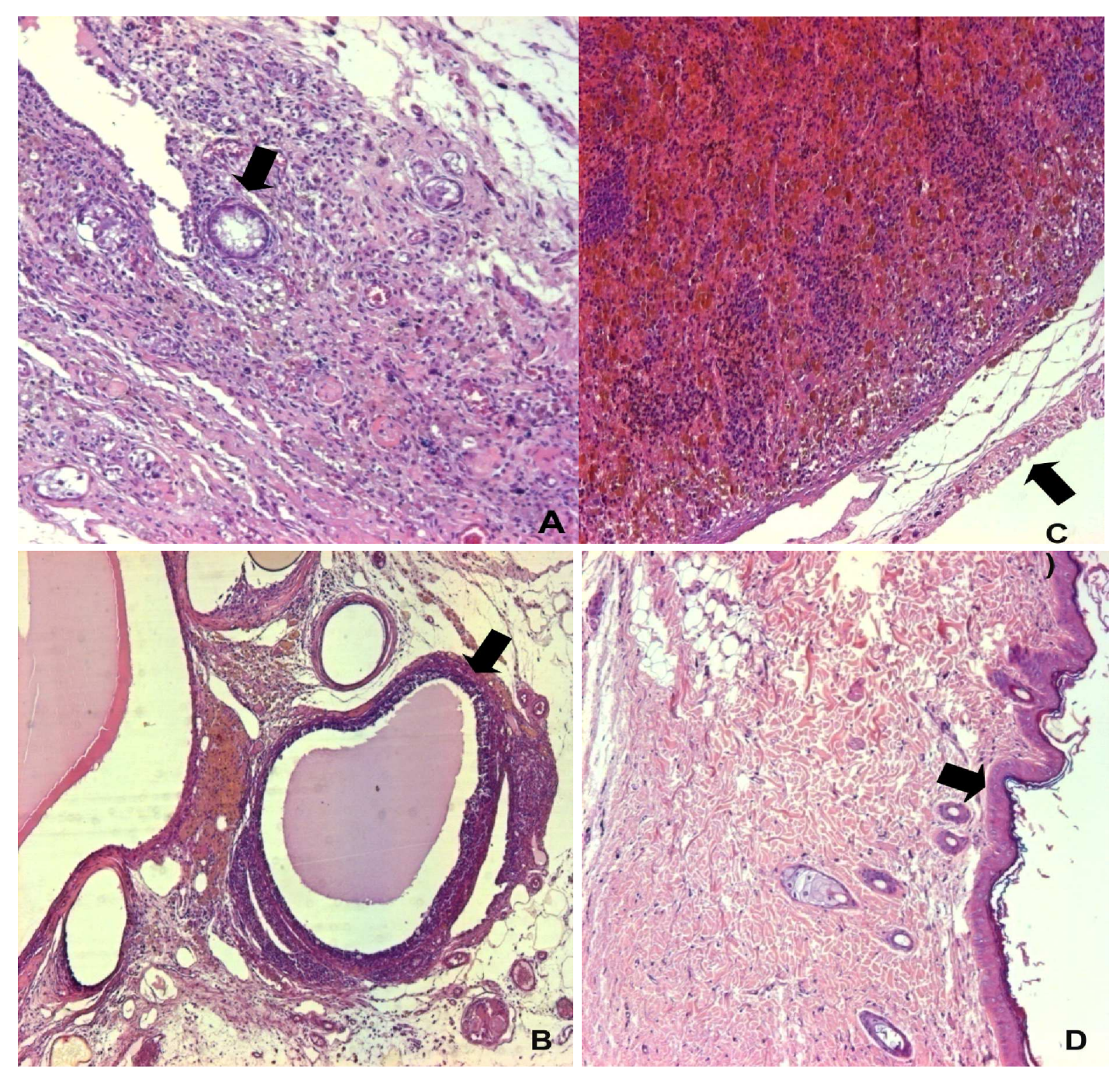

Figure 1 - Histological sections studied preserved in mature coconut water. (HE, 100x).

A) ovarian parenchyma with fibrous tissue and inflammation, with a preserved ovarian follicle (arrow); B) ovarian tissue with follicular cysts indicating tissue degeneration (arrow); C) splenic hemorrhagic tissue with lymphatic follicles, sinusoids capillaries and intact splenic capsule (arrow); D) skin tissue with epidermis (arrow) and dermis with hair follicles and fibrous connective tissue. 
culture $^{15}$. In this study, the coconut water solutions were as effective as the other solutions in the preservation of splenic implants, ovarian and skin. The difficulty in relating the difference between the tissue preservation solution in the study could be due to the short preservation period (six hours) sufficient to determine the maximum time conservative capacity of each solution.

Other authors have reported that the coconut water can be as effective as saline for ovarian follicle preservation under certain conditions ${ }^{16}$. This information would justify the difficulty to highlight differences between the preservation solutions such as Ringer lactate and Belzer. Moreover, this period is sufficient in practice to transport the donor tissue to its implantation in the recipient.

The 3-indole-acetic acid (IAA), present in coconut water, the main plant hormone, can bind to animal growth factors of ovarian tissue and increase its action ${ }^{15}$. However, the present study showed no benefits of coconut-based solutions in the preservation of tissues, which could be due to the presence of substances such as IAA, except for better histological ovarian preservation in mature coconut solution regarding modified coconut solutions and Belzer.

The modified coconut electrolytic solution had a composition similar to the Belzer solution and was subjected to a physico-chemical process of sterilization and pH change, which may have altered the natural properties of the coconut water ${ }^{17}$, justifying the inadequate preservation of ovarian tissue, as well as by Belzer solution. The highest levels of FSH may suggest a lower effectiveness of the Belzer solution for preservation of ovarian function.

One of the main properties of coconut water is attributed to its antioxidant activity, on the ascorbic acid and glutathione content ${ }^{3}$. The antioxidant activity necessary for the preservation solutions ${ }^{18}$ decreases by exposing the coconut water to heat. The highest concentration of potassium in the Belzer and modified coconut solutions could be a factor in explaining the worst preservation capacity, because of the ovarian tissue characteristics ${ }^{19}$. However, the mature coconut water, which has high levels of potassium, was as effective as other substances in the preservation of the implants in the study, with a tendency to better histological preservation of the skin and ovaries.

The absence of glucose in the Belzer solution, the presence of inert substrates as responsible for the osmotic concentration and its high viscosity ${ }^{20}$ may have impaired the preservation of ovarian tissue and perhaps the skin tissue. Other authors observed that preserving substances enriched with nutrient showed better preservation of some tissues such as liver, pancreas and small intestine compared with the Belzer solution ${ }^{21}$.

Coconut water was as effective as the other solutions in the preservation of skin implants. Some change in the chemical composition of coconut water with its aging, sugar changes or other microelements, and reduced enzyme activity, may explain the better preservation of the implants in this solution ${ }^{22}$

This study showed that the coconut water-based solutions were as effective as the other solutions in the preservation of the spleen, ovary and skin of rats for six hours. There is a need to strengthen the findings of this study with studies of other tissues and organs, as well as a greater range of animal species. There is also the need to establish the maximum amount of tissue preservation in chilled coconut water. The coconut water solutions preserved tissue vitality of the spleen, ovary and skin of rats for six hours, while maintaining their function. According to the progress of works to search for a preservation solution, this work could lead to a new, useful patent for Brazil.

\title{
R E S U M O
}

\begin{abstract}
Objetivo: verificar a eficácia da água de coco na preservação de tecidos para transplante. Métodos: cinquenta ratas Wistar foram distribuídas aleatoriamente em cinco grupos, de acordo com as seguintes soluções de preservação para enxertos teciduais: Grupo 1- Ringer lactato, Grupo 2- Solução de Belzer, Grupo 3- Água de coco maduro, Grupo 4- Água de coco verde, Grupo 5- Água de coco modificada. No Grupo 5, a água de coco verde foi modificada à semelhança da solução de Belzer. De cada animal, retirouse o baço, os ovários e um segmento de pele do dorso. Esses tecidos foram preservados durante seis horas em uma das soluções. Em seguida, os enxertos foram reimplantados. A recuperação da função dos tecidos implantados foi avaliada 90 dias após a cirurgia, por meio de cintilografia esplênica, exames de sangue. Os tecidos implantados foram coletados para estudo anatomopatológico. Resultados: as dosagens séricas não apresentaram diferença entre os cinco grupos, exceto pelos animais do Grupo 5, que apresentaram valores mais elevados de lg G do que o Grupo 1, e pelas diferenças em relação ao FSH entre os grupos 1 e 2 (p<0,001), 4 e $2(p=0,03)$, 5 e $2(p=0,01)$. A cintilografia esplênica não foi diferente entre os grupos. O tecido ovariano foi melhor preservado em água de coco maduro $(p<0,007)$. Conclusão: as soluções à base de água de coco preservam baço, ovário e pele de rato durante seis horas, mantendo sua função normal.
\end{abstract}

Descritores: Cocos, Soluções para preservação de órgãos, Transplante autógeno, Baço, Pele, Ovário.

\section{REFERENCES}

1. Southard JH, Belzer FO. Organ preservation. AnnuRev Med.1995;46:235-47.
2. Todo S, Podesta L, Ueda Y, Imventarza O, Casavilla A, Oks A, et al. Comparison of UW with other solutions for liver preservation in dogs. Clin Transplant.1989;3(5):253-9. 
3. Silva $A E$, Cavalcante $L F$, Rodrigues $B A$, Rodrigues JL. The influence of powdered coconut water (ACP-318®) in in vitro maturation of canine oocytes. Reprod Domest Anim.2010;45(6):1042-6.

4. Mühlbacher $F$, Langer $F$, Mittermayer $C$. Preservations solutions for transplantation. Transplant Proc.1999;31(5):2069-70.

5. Braga AA, Malagó R, Anacleto TP, Silva CR, Andreollo NA, Fernandes FL. Histological aspects of autologous transplantation of different fragments of the spleen in rats. Acta Cir Bras.2012;27(12):880-4.

6. Marques RG, Caetano CE, Diestel CF, Lima E, Portela MC, Oliveira $A V$, et al. Critical mass of splenic autotransplant needed for the development of phagocytic activity in rats. Clin Exp Immunol.2012;170(1):77-85.

7. Díaz-García C, Milenkovic M, Groth K,Dahm-Kähler P, Olausson $M$, Brännström M. Ovarian cortex transplantation in the baboon: comparison of four different intra-abdominal transplantation sites. Hum Reprod.2011;26(12):3303-11.

8. Kamran A, Javad FM, Sahram F, Jaber MS. A comparison of survival and secondary contraction in expanded versus conventional fullthickness skin grafts: an experimental study in rats. Eplasty.2012,12:e20.

9. Petroianu A. Esplenectomia subtotal e anastomose esplenorrenal proximal para o tratamento da hipertensão portal. Rev bras cir. 1983;73(2):101-4.

10. Vasconcellos LS, Alberti LR, Petroianu A, Nunes MB. Viabilidade e funçäo endócrina de auto-implantes ovarianos com drenagem pela veia porta ou cava. Reprod clim. 2001;16(4):259-63.

11. Petroianu A, Alberti LR, Vasconcellos LS. Allogeneic and autologous ovarian orthotopic transplantation without a vascular pedicle: morphological, endocrinologic and natural pregnancy assessment. J Obstet Gynaecol Res.2007;33(1):24-31.

12. Alberti LR, Vasconcellos LS, PetroianuA. Avaliação endócrina e morfológica de tranplante autógeno de ovários íntegros e fatiados em coelhas. Rev bras anal clin.2007;39(1):63-6.

13. Sajtos E, Balint A, Brath E,Nemeth N, Peto K, Kovacs J, Galuska L, et al. Long-term following-up of viability of spleen autotransplants in the Beagle canine model. Acta Cir Bras.2012;27(2):95-101.

14. Di Carlo I, Pulvirenti E, Toro A. A new technique for spleen autotransplantation. Surg Innov.2012;19(2):156-61.
15. Lima GL, Costa LL, Cavalcanti DM, Rodrigues CM, Freire FA, Fontenele-Neto JD, et al. Short-term storage of canine preantral ovarian follicles using a powdered coconut water (ACP)-based medium. Theriogenology.2010;74(1):146-52.

16. Costa SHF, Santos RR, Ferreira MAL,Machado VP, Rodrigues APR, Ohashi OM, et al. Preservation of goat preantral follicules in saline or coconut water solution. Bras J vet Res anim Sci.2002;39(6):32430.

17. Awua AK, Doe ED, Agyare R. Exploring the influence of sterilisation and storage on some physicochemical properties of coconut (Cocos nucifera L.) water. BMC Res Notes.2011;4:451.

18. Doliñska B, Ostróika-Cieœlik A, Caban A, Rimantas K, Leszczyñska $L$, Ryszka F. Influence of trace elements on stabilization of aqueous solutions of ascorbic acid.Biol Trace Elem Res.2012;150(1-3):50912.

19. Arnaoutakis GJ, Allen JG, Merlo CA, Baumgartner WA, Conte JV, Shah AS.Low potassium dextran is superior to University of Wisconsin solution in high-risk lung transplant recipients. J Heart Lung Transplant. 2010;29(12):1380-7.

20. Guibert EE, Petrenko AY, Balaban CL, Somov AY, Rodriguez JV, Fuller BJ.Organ preservation: current concepts and new strategies for the next decade. Transfus Med Hemother.2011;38(2):12542.

21. Kimura Y, Okitsu T, Xibao L, Teramae H, Okonogi A, Toyoda K, et al.Improved hypothermic short-term storage of isolated mouse islets by adding serum to preservation solutions. Islets.2013,5(1):4552.

22. Vigliar R, Sdepanian VL, Fagundes-Neto U. Perfil bioquímico da água de coco de coqueiros de região não litorânea. J Pediatr.2006;82(4):308-12.

Received 10/02/2014

Accepted for publication 25/04/2014

Conflict of interest: none

Source of funding: none

Address for correspondence:

Andy Petroianu

E-mail: petroian@medicina.ufmg.br 